\title{
Physicochemical Properties of Jatropha podagrica Biodiesel Blends and Their Effects on Tractor Engine Performance and Emission
}

\author{
S. Nuanual*, P. Maneechot*, P. Thanarak*, A. Phuruangrat** and S. Artkla***† \\ *School of Renewable Energy and Smart Grid Technology (SGTech), Naresuan University, Phitsanulok, 65000, Thailand \\ **Department of Materials Science and Technology, Faculty of Science, Prince of Songkla University, Hat Yai, \\ Songkhla, 90112, Thailand \\ ***Faculty of Liberal Arts and Science, Roi-Et Rajabhat University, 113 Moo 12, Koh Koae Selaphum, Roi Et, 45120, \\ Thailand \\ †Corresponding author: Surachai Artkla; surachaiartkla@hotmail.com
}

Nat. Env. \& Poll. Tech. Website: www.neptjournal.com

Received: $23-10-2019$

Revised: 18-11-2019

Accepted: 16-01-2020

Key Words:

Engine performance

Biodiesel

Energy

Jatropha podagrica

\begin{abstract}
Jatropha biodiesel produced from Jatropha podagrica oil by alkaline-catalysed transesterification was blended with diesel in the ratios of $88: 12 \mathrm{wt} \%$ (B88) and 12:88 wt\% (B12). The fuel properties, consumption rate and exhaust gas emission characteristics of $J$. podagrica biodiesel, diesel and their blends were assessed. The results showed that $J$. podagrica seed oil have similar fatty acid profile with those of Jatropha curcas cultivated in Thailand and other South-East Asian countries. Blending of $J$. podagrica biodiesel and diesel enhanced the fuel properties of the blends, similar to those of the diesel. However, the B88 blend emitted lesser pollutants when compared to B12 and petrol diesel, making it very ideal for use as a promising alternative to the petrol diesel used in the mini tractor for farming activities. The results from the current study form a basis for further research on the use of B88

as a fuel source.
\end{abstract}

\section{INTRODUCTION}

Global energy demand is growing as a result of rapid economic and population growth (Salvi \& Panwar 2012). The worldwide primary energy demand is estimated to increase by $1.5 \%$ per annum from 2007 to 2030 with an overall increase of $40 \%$ (Elango \& Senthilkumar 2011). Currently, the world's economy is mostly dependent on fossil fuels, a situation which has raised serious concerns due to the limited reserves and the negative effects of fossil fuel combustion (Borugadda \& Goud 2012). Energy security, environmental health, and greenhouse gases (GHGs) concerns associated with fossil fuel combustion have resulted in the development of environmentally friendly and renewable alternative energy sources (Abbaszaadeh et al. 2012).

In recent years, utilization of biofuel has attracted global attention, especially in the transportation industry, because of its general compatibility with conventional liquid transport fuel from fossil sources (Salvi \& Panwar 2012). Biodiesel is a vital renewable clean biofuel that shares similar characteristics with petrol diesel, making it a promising alternative (Ibeto et al. 2012). Biodiesel is biodegradable, renewable, has low emissions, and not toxic (Atabani \& Cesar 2014). It is produced from animal fats and vegetable oils (Aransiola et al. 2014). First generation biodiesel is produced from food-based oils such as rapeseed, soybean, and palm oils (Gülsen et al. 2014). However, biodiesel from these edible oil crops is not sustainable (Zhang et al. 2015). Continuous use of these edibles crops creates a food versus fuel crisis, resulting in an increase in their demand and price, adding up to the cost of biodiesel production (Larran et al. 2015). Consequently, biodiesel production from non-food oil crops has gain global attention (Atabani \& Cesar 2014). Second generation biodiesel from non-food oil crops is more economical as these crops are found all over the world and can survive under all types of environmental conditions and lands without intensive husbandry (Atabani et al. 2013). In view of this, several researches have been done on Jatropha, a non-edible oil, as a potential substitute for petrol diesel.

Jatropha oil is relatively easy to store, transport, and safe to handle. However, the high viscosity of Jatropha oil causes insufficient atomization and incomplete combustion when used directly in diesel engines (Forson et al. 2004). Modification of the Jatropha oil through techniques such as heating, transesterification, and blending with petrol diesel has been used to eliminate atomization and combustion problems associated with high viscosity (Agarwal \& Agarwal 
2007). A combination of these techniques has been reported by several researchers as enhancing the fuel properties of Jatropha oil, comparable to that of petrol diesel (Agarwal \& Agarwal 2007, Chauhan et al. 2011, Chen et al. 2013).

Notwithstanding the potential of Jatropha oil, research works have mainly focused on Jatropha curcas. However, there are other equally important Jatropha species yet to be exploited. Our study effort is aimed at using Jatropha podagrica oil as a substitute for diesel fuel with no engine modification. Our research highlights the physio-chemical properties of $J$. podagrica seed oil, and the performance and emission characteristics of J. podagrica biodiesel, Jatropha biodiesel-diesel blends in a mini-tractor (Kubota M7040, 4-stroke, 3-inches, 20 HP) engine. For comparison, diesel fuel was also tested and set as the benchmark. This is important because of the high energy consumption in the agriculture sector of Thailand. Tillage and other farm operations are expensive due to high fossil fuel consumption (Youssef et al. 2014), and on the other hand, is ecologically unfavourable (Borugadda \& Goud 2012). Therefore, a fuel type that has less consumption rate, with fewer emissions will reduce farmers production cost and contribute immensely to environmental sustainability.

\section{MATERIALS AND METHODS}

\section{Extraction of Jatropha Oil}

Healthy whole $J$. podagrica seeds were collected from field crops in Nong YaPlong District, Petchaburi, Thailand. The $50 \mathrm{~kg}$ of the unshelled seeds were thoroughly washed and dried under room temperature for 3 months. The seeds were then shelled and dried in a hot air oven at $60^{\circ} \mathrm{C}$ for $12 \mathrm{~h}$. Approximately $40 \mathrm{~kg}$ of the dried kernels were finely milled with an SM 100, Rtsch, Rheinis-che StraBe 36-D-42781 (Haan, North Rhine-Westphalia, Germany) miller for 30 min. From the dried kernels, $39.2 \mathrm{~kg}$ dough was obtained and used for the oil extraction. The dough was continuously stirred in a distilled water for $15 \mathrm{~min}$ and the mixture filtered with a 5-micron filter to separate the solid waste from the solvent. The solvent was kept under room temperature for $12 \mathrm{~h}$ to enable the oil layer separate from the water. The oil layer was then strain and kept in a rotary evaporator to remove excess moisture. Finally, the Jatropha oil obtained was held in a 100-litre oxygen-free chamber for 3 months to precipitate smaller particles. After the 3 months storage, the yellowish brown-liquid oil (triglyceride) was filtered with 3-micron filter and transferred to the stock-solution chamber for transesterification.

\section{Fatty Acid Analysis}

The fatty acid profile of the seed oil was evaluated using the gas chromatography (GC, Agilent 6890, Agilent Technologies Inc., CA, USA) fitted with a flame ionization detector (FID). The carrier gas was helium at the flow rate of $1 \mathrm{~mL} / \mathrm{min}$. The fatty acid compositions were identified with an HP-FFAP capillary column $(25 \mathrm{~m} \times 0.25 \mathrm{~mm} ; 0.22 \mathrm{~mm}$ film thickness; Agilent Technologies Inc., CA, USA). The initial temperature of the oven was held at $180^{\circ} \mathrm{C}$ for $50 \mathrm{~min}$ and increased to $220^{\circ} \mathrm{C}$ at the rate of $10^{\circ} \mathrm{C} / \mathrm{min}$. The injector and FID temperatures were set at $220^{\circ} \mathrm{C}$. The total oil volume of $10 \mu \mathrm{L}$ was injected into the column at the flow rate of $1 \mathrm{~mL} / \mathrm{min}$.

\section{Transesterification Process}

Alkaline-catalysed transesterification was carried out in this study as described by (Mofijur et al. 2013). The conditions for the transesterification process were $6: 1 \mathrm{M}$ ratio of $J$. podagrica oil to methanol, $1 \%$ potassium hydroxide $(\mathrm{KOH})$ as a catalyst, a reaction time of $60 \mathrm{~min}$, continuous stirring at a speed of $600 \mathrm{rpm}$, and a temperature of $60^{\circ} \mathrm{C}$. The mixture was then kept in a separating funnel for $12 \mathrm{~h}$ to separate the biodiesel from glycerol and other impurities. The glycerol and other impurities were then disposed of. The methyl ester obtained was then placed in a rotary evaporator to evaporate the excess methanol and gently washed with distilled water at $60^{\circ} \mathrm{C}$ to remove the remaining impurities and glycerol. The washing was repeated severally till a neutral $\mathrm{pH}$ was attained. Finally, the biodiesel was dried in a rotary evaporator.

\section{Experimental Fuels}

After the transesterification process, two Jatropha biodiesel-diesel blends were prepared in the ratios of 88:12 wt\% (B88) and 12:88 wt\% (B12). The blending was done at the speed of $2000 \mathrm{rpm}$ with a homogenizer machine. The crude Jatropha oil, methyl ester, and petrol diesel were set as test fuels. The test fuels and blends were then tested in the mini-tractor (Kubota M7040, 4-stroke, 3-inches, 20 HP) engine.

\section{Physicochemical Properties of the Fuels}

The standard methods of the Association of Official Analytical Chemists (AOAC 2006), were adopted to determine the physicochemical properties of the seed oil, methyl ester, diesel, and blends. Properties such as viscosity, density, acids value, specific gravity, iodine number, saponification values and free fatty acids were analysed. The calorific value, carbon residues, sulphur content, cloud point, pour point, and flash point were also evaluated as described by the American Society for Testing and Materials (ASTM) D240, D4530, D6667, D2500, and D93, respectively.

\section{Engine Performance Test}

The mini-tractor (Kubota M7040, 4-stroke, 3-inches, 20 $\mathrm{HP}$ ) engine was used to evaluate the test fuels and blends 
for engine fuel consumption rate $(\mathrm{mL} / \mathrm{h})$ at various speeds (1,500-2,300 rpm) and exhaust emissions at the maximum speed of 2,300 rpm. The exhaust emission gases, nitrogen oxides (NOx), hydrocarbons (HCs), and carbon monoxide (CO), were measured with the exhaust gas analyser $(\mathrm{BOSCH}$ BEA-350).

\section{Statistical Analysis}

One-way analysis of variance (ANOVA) and comparison of means (Tukey's test at 5\% significance level) were done using SPSS version 17.0 (SPSS Inc., Chicago, IL). The mean values with their corresponding standard deviations were presented.

\section{RESULTS AND DISCUSSION}

\section{Compositional Analysis of Fatty Acids in J. podagrica Oil}

A total of $14.22 \mathrm{~kg}$ crude oil yield was realized, representing $28.4 \%$ by weight per $\mathrm{kg}$ of the unshelled Jatropha kernels. It is well known that the crude oil content of Jatropha is approximately 30-35\% (Pandey et al. 2012). Forson et al. (2004) reported a $6.88 \mathrm{~kg}$ of oil from $32 \mathrm{~kg}$ of unshelled Jatropha seeds using a simple mechanical ram-press, which represented a $21.5 \%$ oil yield per $\mathrm{kg}$ of the unshelled seeds. The major fatty acid components of J. podagrica seed oil in the current study were the unsaturated fatty acids linoleic and oleic acids (Table 1). The study also revealed the presence of saturated fatty acids, mainly palmitic and stearic acids, in the seed oil. Several researchers have reported linoleic, oleic, palmitic, and stearic acids as the main fatty acid composition of J. curcas seed oil (Deng et al. 2010, Emil et al. 2010, Ilham
\& Saka 2010, Jain \& Sharma 2010a, Jain \& Sharma 2010b). $J$. podagrica seed oil in the current study share similar fatty acid profile with those of J. curcas cultivated in Thailand, Malaysia and Indonesia (Table 1).

\section{Physicochemical Properties of the Fuels}

Transesterification of J. podagrica seed oil is very important in its consumption as fuel. Due to the low acid value of the seed oil in this study, alkaline transesterification was carried out. The physicochemical properties of raw J. podagrica seed oil, methyl ester, diesel, and blends are shown in Table 2 . The viscosity of $J$. podagrica seed oil in the current study was reduced after the transesterification process. However, the value was still higher when compared to that of the diesel. A blend of the methyl ester and diesel further reduced the viscosity close to that of the diesel. The viscosity of the oil is a very important property in assessing its suitability as a liquid fuel. High viscosity inhibits the injection process and delays ignition of the engine (Ong et al. 2013). The low viscosity of the blend is very significant in enhancing its flow and atomization characteristics, making it very suitable as liquid fuel for diesel engines. Similar to viscosity, the density, acid value, specific gravity, cloud point, pour point, flash point, sulphur content, and carbon residue of the seed oil were reduced after transesterification. Blending the biodiesel with the diesel again caused a further reduction to these properties except for the sulphur content which increased slightly. However, transesterification of the seed oil helped to increase the calorific value. The value was further increased after blending with petrol diesel. Transesterification and further blending with diesel in this research enhanced the physicochemical

Table 1: Fatty acid composition of J. podagrica seed oil.

\begin{tabular}{|c|c|c|c|c|}
\hline Fatty acid composition (\%) & J. podagrica (This study) & J. curcas (Thailand)* & $\begin{array}{l}J . \text { curcas (Malay- } \\
\text { sia)* }\end{array}$ & J. curcas (Indonesia)* \\
\hline Myristic acid (C14:0) & 0.10 & - & 0.10 & 0.10 \\
\hline Palmitic acid (C16:0) & 13.80 & 15.20 & 14.20 & 14.50 \\
\hline Heptadecanoic acid (C17:0) & 0.10 & 0.10 & 0.10 & 0.10 \\
\hline Stearic acid (C18:0) & 7.80 & 6.80 & 7.00 & 7.00 \\
\hline Arachidic acid (C20:0) & 0.30 & 0.20 & 0.20 & 0.20 \\
\hline Palmitoleic acid (C16:1) & 0.70 & 0.70 & 0.70 & 0.70 \\
\hline Oleic acid (18:1) & 44.50 & 44.60 & 44.70 & 42.40 \\
\hline Linoleic acid (C18:2) & 32.50 & 32.20 & 32.80 & 34.60 \\
\hline -Linolenic acid (C18:3) & 0.20 & 0.20 & 0.20 & 0.20 \\
\hline Saturated fatty acids & 22.10 & 22.30 & 21.60 & 21.90 \\
\hline Unsaturated fatty acids & 77.90 & 77.70 & 78.40 & 77.90 \\
\hline
\end{tabular}

Source: (Emil et al. 2010, Supamathanon et al. 2011) 
properties of the blends. The properties of the blends were comparable to that of the diesel (Table 2). Modification of vegetable oils to give them similar combustion properties as petrol diesel is very important in their use as a liquid fuel. Transesterification, pyrolysis, micro-emulsion, and blending are major processes for the modification of vegetable oils including that of Jatropha seed (Agarwal \& Agarwal 2007). Several researchers have reported of the enhancement of vegetable oil after blending with diesel at various ratios (Agarwal \& Agarwal 2007, Chen et al. 2013, Mofijur et al. 2013, Rehman et al. 2011).

\section{Fuel Consumption}

The fuel consumption rate of the mini-tractor (Kubota M7040, 4-stroke, 3-inches, $20 \mathrm{HP}$ ) at different engine speeds used in the current study is given in Table 3. Fuel consumption increased as the engine speed was increased from 1,500-2,300 for the different fuel types. Jatropha biodiesel consumption was very high when compared to the other fuel types. The consumption rate of the other fuel types was however similar. The low B88, B12, and petrol diesel consumption, when compared to that of Jatropha biodiesel, may be attributed to their high calorific value (Chen et al. 2013). Agarwal \& Agarwal (2007) reported that the low calorific value of seed oil from Jatropha results in high fuel consumption to maintain the level of energy input to engines. The decrease in the viscosity of B88 and B12 may have also contributed to the low consumption when compared to that of Jatropha biodiesel (Chauhan et al. 2010). Fuel atomization of the blends may have been significantly improved due to the

Table 2: Physicochemical properties of J. podagrica seed oil, methyl ester, diesel, and blend.

\begin{tabular}{|c|c|c|c|c|c|}
\hline Properties & Jatropha oil & Jatropha biodiesel & Diesel & B88 & B12 \\
\hline Viscosity $\left(\mathrm{cP}, 40^{\circ} \mathrm{C}\right)$ & 42.8 & 5.23 & 3.50 & 3.80 & 3.60 \\
\hline Density $\left(20^{\circ} \mathrm{C}, \mathrm{kg} / \mathrm{m}^{3}\right)$ & 0.90 & 0.88 & 0.84 & 0.87 & 0.85 \\
\hline Acid value (mg KOH/g) & 2.13 & 0.52 & 0.12 & 0.32 & 0.12 \\
\hline Specific gravity $\left(\mathrm{g} / \mathrm{cm}^{3}\right)$ & 0.93 & 0.90 & 0.85 & 0.87 & 0.86 \\
\hline Calorific value $(\mathrm{MJ} / \mathrm{kg})$ & 39.20 & 41.05 & 42.80 & 41.40 & 42.20 \\
\hline Cloud point $\left({ }^{\circ} \mathrm{C}\right)$ & 8 & 1 & -10 & -4.3 & -8 \\
\hline Pour point $\left({ }^{\circ} \mathrm{C}\right)$ & 5 & 2 & -13 & -8 & -10 \\
\hline Flash point $\left({ }^{\circ} \mathrm{C}\right)$ & 180 & 135 & 76 & 85 & 79 \\
\hline Sulphur content (\%) & 0.007 & 0.002 & 0.043 & 0.003 & 0.040 \\
\hline Carbon residue $(\%, w / w)$ & 2.35 & 1.23 & 0.16 & 0.75 & 0.50 \\
\hline Iodine number $(\mathrm{g} / 100 \mathrm{~g})$ & 86.80 & - & - & - & - \\
\hline Saponification value $(\mathrm{mg} \mathrm{KOH} / \mathrm{g})$ & 183.50 & - & - & - & - \\
\hline Free fatty acids (FFA, \%) & 2.10 & - & - & - & - \\
\hline
\end{tabular}

Table 3: Fuel consumption rate of the mini-tractor (Kubota M7040, 4-stroke, 3-inches, 20 HP).

\begin{tabular}{|c|c|c|c|c|}
\hline $\begin{array}{l}\text { Engine operation } \\
\text { (RPM) }\end{array}$ & $\begin{array}{l}\text { Jatropha biodiesel } \\
(\mathrm{mL} / \mathrm{h})\end{array}$ & $\begin{array}{l}\text { B88 } \\
(\mathrm{mL} / \mathrm{h})\end{array}$ & $\begin{array}{l}\text { B12 } \\
(\mathrm{mL} / \mathrm{h})\end{array}$ & $\begin{array}{l}\text { Diesel } \\
(\mathrm{mL} / \mathrm{h})\end{array}$ \\
\hline 1,500 & 520 & 502 & 502 & 502 \\
\hline 1,600 & 525 & 501 & 501 & 500 \\
\hline 1,700 & 550 & 543 & 542 & 542 \\
\hline 1,800 & 630 & 590 & 590 & 589 \\
\hline 1,900 & 670 & 632 & 632 & 632 \\
\hline 2,000 & 730 & 699 & 699 & 698 \\
\hline 2,100 & 770 & 764 & 763 & 762 \\
\hline 2,200 & 850 & 809 & 809 & 808 \\
\hline 2,300 & 910 & 858 & 875 & 875 \\
\hline
\end{tabular}


low viscosity (Agarwal \& Agarwal 2007). The difference in fuel density observed earlier (Table 2) may have also contributed to the variations in fuel consumption. The decrease in the fuel density results in less discharge of fuel for the same displacement of the plunger in the fuel injection pump (Chauhan et al. 2011). This leads to less fuel consumption as was observed in B88, B12 and diesel in comparison to Jatropha biodiesel in our current study.

\section{Gaseous Emissions}

The emissions levels of NOx (Fig. 1), HC (Fig. 2), and $\mathrm{CO}$ (Fig. 3) as a result of using the various fuel types were assessed by operating the engine at the maximum speed of $2300 \mathrm{rpm}$. The assessment revealed that Jatropha biodiesel and its blends emitted significantly $(\mathrm{p}<0.05)$ higher NOx when compared to petrol diesel. The NOx emission levels significantly $(\mathrm{p}<0.05)$ increased with an increase in the Jatropha biodiesel percentage. This may be attributed to the higher oxygen content in biodiesel when compared to petrol diesel. This causes complete combustion with the biodiesel and its blend increasing the combustion temperature and subsequent increase in NOx emissions (Mofijur et al. 2013). Similar observations have been reported by several researchers (Chauhan et al. 2011, Mofijur et al. 2013, Dhar et al. 2012). However, the emission levels of HC and CO were significantly $(\mathrm{p}<0.05)$ higher with the use of petrol diesel when compared to those of the Jatropha biodiesel and its blends. As the percentage of the petrol diesel increased, significantly $(\mathrm{p}<0.05)$ more $\mathrm{HC}$ and $\mathrm{CO}$ were emitted. The complete combustion that occurs with the use of biodiesel and blends with high biodiesel percentage leads to a decrease in the $\mathrm{CO}$ and $\mathrm{HC}$ emissions (Chauhan et al. 2011).

The performance of the engine and the level of pollutants it emits are very critical factors in the use of biodiesel and its blends as an alternative fuel to petrol diesel (Chen et al. 2013). The use of biodiesel and its blends as fuel for engines contributes less emissions of carbon monoxide, particulate matter, sulphur oxides, smoke, and polyaromatic hydrocarbons (Agarwal \& Agarwal, 2007). However, petrol diesel combustion is one of the main contributors to environmental pollution worldwide. These pollutants have a serious impact on the health of the environment and humans (Mofijur et al. 2013). One of the major advantages of using biodiesel as an alternative fuel is that it can be blended with petrol diesel to enhance its performance as well as significantly reducing emission of pollutants (Chauhan et al. 2010). The successful use of biodiesel-petrol diesel blends at different ratios has been reported by several researches across the globe (Atabani \& Cesar 2014, Mofijur et al. 2013, Rehman et al. 2011, Tsolakis et al. 2007). Among the different types of fuel in the current study, B 88 and B12 share similar properties with the petrol diesel. However, B88 emits less pollutant, making

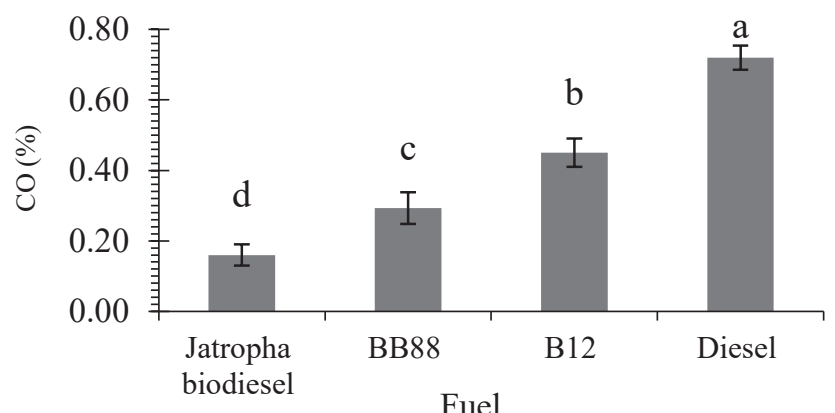

Fig. 1: Nitrogen oxides emissions for different fuel types at the maximum speed of $2300 \mathrm{rpm}$.

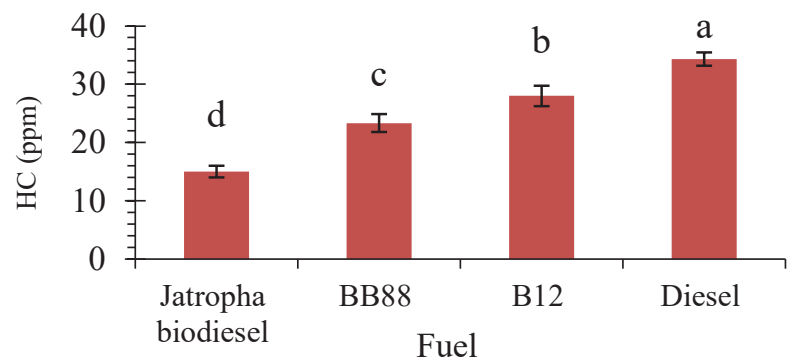

Fig. 2: Hydrocarbon emissions for different fuel types at the maximum speed of $2300 \mathrm{rpm}$. 


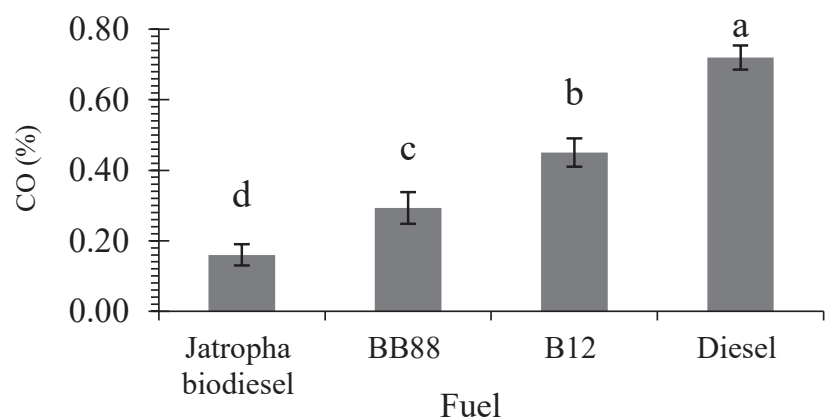

Fig. 3: Carbon monoxide emissions for different fuel types at a maximum speed of $2300 \mathrm{rpm}$.

it very ideal for use as a promising alternative to the petrol diesel in the mini tractor for farming purposes.

\section{CONCLUSION}

Jatropha biodiesel-petrol diesel blend can be an alternative fuel for mini tractor during farming activities. The Jatropha biodiesel-petrol diesel blends in the current study share similar characteristics and properties with petrol diesel. However, B88 emits less pollutant when compared to B12 and petrol diesel, making it a potential alternative fuel. This study forms a strong basis for further research on the use of B88 as the fuel source for diesel engines.

\section{ACKNOWLEDGEMENTS}

We acknowledge the financial support provided by the National Research Council of Thailand (NRCT). Equipment supports were from Scientific Equipment Center, Suranaree University of Technology, Nakhon Ratchasima, 30000, Thailand; Research Laboratory Equipment Center, Maha Sarakham University, Maha Sarakham, 44000, Thailand and the Faculty of Liberal Arts and Science, Roi-Et Rajabhat University (RERU), 45120, Thailand. The assistance of P. Sriprapakhan is also acknowledged.

\section{REFERENCES}

Abbaszaadeh, A., Ghobadian, B., Omidkhah, M.R. and Najafi, G. 2012. Current biodiesel production technologies: A comparative review. Energy Convers. Manag., 63: 138-148.

Agarwal, D. and Agarwal, A.K. 2007. Performance and emissions characteristics of Jatropha oil (preheated and blends) in a direct injection compression ignition engine. Appl. Therm. Eng., 27: 2314-2323.

AOAC 2006. Official Methods of Analysis. 18th ed., Association of Official Analytical Chemists, Washington, DC, U.S.A.

Aransiola, E.F., Ojumu, T.V., Oyekola, O.O., Madzimbamuto, T.F. and Ikhu-Omoregbe, O.I.O. 2014. A review of current technology for biodiesel production: State of the art. Biomass Bioenergy, 61: 276-297. Atabani, A.E. and César, A.D.S. 2014. Calophyllum inophyllum L. - A prospective non-edible biodiesel feedstock. Study of biodiesel production, properties, fatty acid composition, blending and engine performance. Renew. Sust. Energ. Rev., 37: 644-655.

Atabani, A.E., Mahlia, T.M.I., Anjum, B.I., H. H. Masjuki, H.H., Chong, W.T. and Lee, K.T. 2013. Investigation of physical and chemical properties of potential edible and non-edible feedstocks for biodiesel production, a comparative analysis. Renew. Sust. Energ. Rev., 21: 749-755.

Borugadda, V.B. and Goud, V.V. 2012. Biodiesel production from renewable feedstocks: Status and opportunities. Renew. Sust. Energ. Rev., 16: 4763-4784.

Chauhan, B.S., Kumar, N. and Cho, H.M. 2011. A study on the performance and emission of a diesel engine fuelled with Jatropha biodiesel oil and its blends. Energy, 37: 616-622.

Chauhan, B.S., Kumar, N., Du Jun, Y. and Lee, K.B. 2010. Performance and emission study of preheated Jatropha oil on medium capacity diesel engine. Energy, 35: 2484-2492.

Chen, L.Y., Chen, Y.H., Hung, Y.S., Chiang, T.H. and Tsai, C.H. 2013. Fuel properties and combustion characteristics of Jatropha oil biodiesel-diesel blends. J. Taiwan Inst. Chem. E., 44: 214-220.

Deng, X., Fang, Z. and Liu, Y.H. 2010. Ultrasonic transesterification of Jatropha curcas L. oil to biodiesel by a two-step process. Energ. Convers. Manage., 51: 2802-2807.

Dhar, A., Kevin, R. and Agarwal, A.K. 2012. Production of biodiesel from high-FFA neem oil and its performance, emission and combustion characterization in a single cylinder DICI engine. Fuel Process. Technol., 97: 118-129.

Elango, T. and Senthilkumar, T. 2011. Combustion and emission characteristics of a diesel engine fuelled with jatropha and diesel oil blends. Thermal Science, 15: 1205-1214.

Emil, A., Yaakob, Z., Satheesh Kumar, M., Jahim, J.M. and Salimon, J. 2010. Comparative evaluation of physicochemical properties of jatropha seed oil from Malaysia, Indonesia and Thailand. J. Am. Oil Chem. Soc., 87: 689-695.

Forson, F.K., Oduro, E.K. and Hammond-Donkoh, E. 2004. Performance of jatropha oil blends in a diesel engine. Renewable Energy, 29: $1135-1145$.

Gülsen, E., Olivetti, E., Freire, F., Dias, L. and Kirchain, R. 2014. Impact of feedstock diversification on the cost-effectiveness of biodiesel. Appl. Energy, 126: 281-296.

Ibeto, C.N., Okoye, C.O.B. and Ofoefule, A.U. 2012. Comparative study of the physicochemical characterization of some oils as potential 
feedstock for biodiesel production. ISRN Renew. Energ., 2012, Article ID 621518,5 pages.

Ilham, Z. and Saka, S. 2010. Two-step supercritical dimethyl carbonate method for biodiesel production from Jatropha curcas oil. Bioresour. Technol., 101: 2735-2740.

Jain, S. and Sharma, M.P. 2010a. Biodiesel production from Jatropha curcas oil. Renew. Sust. Energ. Rev., 14: 3140-3147.

Jain, S. and Sharma, M.P. 2010b. Kinetics of acid base catalyzed transesterification of Jatropha curcas oil. Bioresour. Technol. 101: 7701-7706.

Larran, A., Jozami, E., Vicario, L., Feldman, S.R., Podestá, F.E. and Permingeat, H.R. 2015. Evaluation of biological pretreatments to increase the efficiency of the saccharification process using Spartina argentinensis as a biomass resource. Bioresour. Technol., 194: 320-325.

Mofijur, M., Masjuki, H.H., Kalam, M.A. and Atabani, A.E. 2013. Evaluation of biodiesel blending, engine performance and emissions characteristics of Jatropha curcas methyl ester: Malaysian perspective. Energy, 55: 879-887.

Ong, H.C., Silitonga, A.S., Masjuki, H.H., Mahlia, T.M.I., Chong, W.Y. and Boosroh, M.H. 2013. Production and comparative fuel properties of biodiesel from non-edible oils: Jatropha curcas, Sterculia foetida and Ceiba pentandra. Energ. Convers. Manage., 73: 245-255.

Pandey, V.C., Singh, K., Singh, J.S., Kumar, A., Singh, B. and Singh, R.P.
2012. Jatropha curcas: A potential biofuel plant for sustainable environmental development. Renew. Sust. Energ. Rev., 16: 2870-2883.

Rehman, A., Phalke, D.R. and Pandey, R. 2011. Alternative fuel for gas turbine: Esterified jatropha oil-diesel blend. Renew. Energ., 36: 2635-2640

Salvi, B.L. and Panwar, N. L. 2012. Biodiesel resources and production technologies-A review. Renew. Sust. Energ. Rev., 16: 3680-3689.

Supamathanon, N., Wittayakun, J. and Prayoonpokarach, S. 2011. Properties of Jatropha seed oil from Northeastern Thailand and its transesterification catalyzed by potassium supported on $\mathrm{NaY}$ zeolite. J. Ind. Eng. Chem., 17: 182-185.

Tsolakis, A., Megaritis, A., Wyszynski, M.L. and Theinnoi, K. 2007. Engine performance and emissions of a diesel engine operating on diesel-RME (rapeseed methyl ester) blends with EGR (exhaust gas recirculation). Energy, 32: 2072-2080.

Youssef, M., Khoramivafa, M. and Mondani, F. 2014. Integrated evaluation of energy use, greenhouse gas emissions and global warming potential for sugar beet (Beta vulgaris) agroecosystems in Iran. Atmos. Environ., 92: 501-505.

Zhang, H., Zhou, Q., Chang, F., Pan, H., Liu, X.F., Li, H., Hu, D.Y. and Yang, S. 2015. Production and fuel properties of biodiesel from Firmiana platanifolia $\mathrm{L}$. as a potential non-food oil source. Ind. Crops Prod., 6: 768-771. 